УДК 004.085

\author{
В. В. Петров, А. А. Крючин, Є. В. Беляк, О. В. Шиховець \\ Інститут проблем реєстрації інформації НАН України \\ вул. М. Шпака, 2, 03113 Київ, Україна
}

\title{
Носії довготермінового зберігання даних
}

Наведено результати аналізу технологій створення носіїв для довготермінового зберігання даних. Показано, щуо використання жорстких магнітних дисків і твердотільної пам'яті тільки частково вирішує проблему довготермінового зберігання інформачії. Особливу увагу приділено сучасним технологіям зберігання даних на оптичних носіях. Показано, щуо новітні розробки оптичних носїв спрямовано на суттеве збільшення ємності оптичних носіїв за рахунок використання наноструктурованих реєструвальних матеріалів.

Ключові слова: оптичні носії, довготермінове зберігання інформаиії, голографічна пам'ять, наноструктуровані реєструвальні матеріали, міграція даних.

\section{Вступ}

Зростаючий обсяг інформації (відповідно до сучасних прогнозів, об'єми даних будуть зростати експоненційно), яка представлена у цифровому вигляді, призводить до того, що питання про зберігання інформації на цифрових носіях стає все більш важливим. Спостерігаються тенденції у зберіганні даних, що змінюють глобальні підходи до цієї проблеми, а саме збільшення обсягу життєво важливих даних для суспільства, переміщення даних у хмару та збільшення кількості пристроїв, які створюють дані без участі людини. Ефективне та надійне зберігання інформації $є$ критично важливим у кожній галузі. За оцінками Міжнародної корпорації даних (IDC) обсяг даних, які накопичено по всьому світу, в 2016 році становив 16 ЗБ і має збільшиться до 163 ЗБ у 2025 році. В останні роки спостерігається щорічне зростання обсягів інформації на 40 \% [1]. У 2018 році загальний обсяг даних, які «містяться» в дата-центрах, досягне 1450 Ебайт [2]. Значна частина інформації підлягає довготерміновому зберіганню: це дані про тенденції розвитку суспільства, про наукові відкриття, генетична інформація, страхова документація, історичні факти, книги, фільми тощо. Дослідження в галузі астрофізики, біології, географії, соціальних наук і бізнесу генерують велику кількість даних, які мають зберігатися тривалий час для їхнього ефективного використання. У біологічній

(C) В. В. Петров, А. А. Крючин, Є. В. Беляк, О. В. Шиховець 
науці проводяться довгострокові експерименти з вивчення еволюції і мутації генів [3]. Об'єктами, що потребують довготермінового зберігання, є об'єкти культурного надбання, внесені до Міжнародного реєстру програми ЮНЕСКО «Пам'ять світу». Останнім об'єктом, який представлено Україною, є комплекс архівних документів, що пов'язані з аварією на Чорнобильській АЕС. Цей архівний пакет всебічно відображає причини, перебіг і наслідки аварії - найбільшої техногенної катастрофи XX століття, містить документи стосовно розвитку атомної енергетики, будівництва атомних електростанцій, вибуху на ЧАЕС 26 квітня 1986 року, реакції влади на аварію, радіаційного забруднення територій [4]. Проте сучасні електронні носії інформації не можуть забезпечити зберігання великих обсягів даних протягом тривалого часу. При вирішенні проблеми вибору типів носіїв для архівного зберігання даних завжди існує необхідність збалансувати вартість носіїв, продуктивність пристроїв і час зберігання даних. Необхідно визначити типи пам'яті, використання яких дозволить вирішити проблему довготермінового зберігання великих обсягів інформації.

\section{Анаміз характеристик магнітних носіїв довготермінового зберігання даних}

У сучасних інформаційних системах головним типом пам'яті для зберігання великих обсягів інформації є жорсткі магнітні диски, щільність запису даних на яких та об’єм пам'яті постійно збільшуються. В останні роки збільшення щільності запису досягається завдяки використанню низки технологій, а саме черепичного магнітного запису (дозволяє забезпечити щільність запису 1 Тбіт/дм², а в перспективі використання двовимірного магнітного запису дозволить досягти щільності запису 1,5 Тбіт/дм²). Використання комбінованих систем магнітного й оптичного запису (технологія HAMR) дозволяє досягти щільності запису 2 Тбіт/дм². Запис на гранульованих магнітних середовищах з використанням технології блочної сополімерізації дозволяє забезпечити щільність запису інформації 10 Тбіт/дм² [5]. Проте, в останні роки спостерігається зменшення швидкості зростання щільності запису на жорстких магнітних дисках (рис. 1).

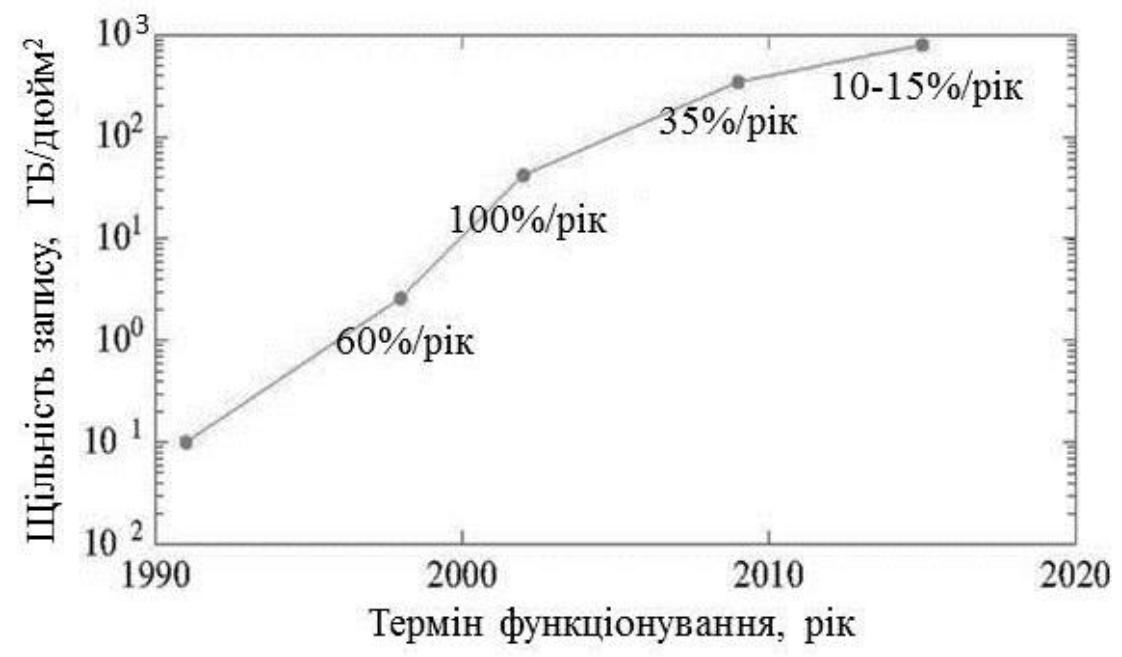

Рис. 1. Зростання щільності магнітного запису [6], дюйм² 
Ємність жорстких магнітних дисків досягла 10 Тбайт (січень 2018) [2]. Виробники HDD також намагаються збільшити ємність за рахунок використання нових конструкцій жорсткого диска. Одна $з$ технологій, яка дозволяє підвищити ємність магнітних HDD, полягає у використанні підкладок, що виготовлені зі спеціального скла, що дозволить жорстким дискам майбутнього покоління перейти через відмітку в 20 Тбайт. Скляні підкладки, за рахунок їхньої міцності, можуть бути більш тонкими, ніж алюмінієві, що дозволить розміщувати додаткові підкладки у корпусі жорсткого диска [7]. Крім цього, продовжується розвиток HDD, корпуси яких заповнені гелієм. Такі диски витрачають менше електроенергії і мають меншу вагу (порівняно 3 «повітряними» моделями). При цьому, за підрахунками компанії Backblaze, показник відмов дисків з гелієм нижче, ніж у звичайних жорстких дисків [2].

Однак технічні рішення, які дозволили значно збільшити ємність жорстких магнітних дисків, не вирішують проблеми довготермінового надійного зберігання даних. Сдиним шляхом створення систем довготермінового зберігання даних на жорстких магнітних дисках є проведення кожні 2-3 роки повної міграції даних на нові носії. Проведення такої процедури є досить витратним заходом і пов'язане 3 можливістю втрати частини даних, хоча забезпечує перехід до використання новітніх технічних засобів [8]. В останні роки спостерігається зменшення обсягу виготовлених жорстких магнітних дисків і зростання обсягу виготовленої SSD-пам’яті (рис. 2) [9].

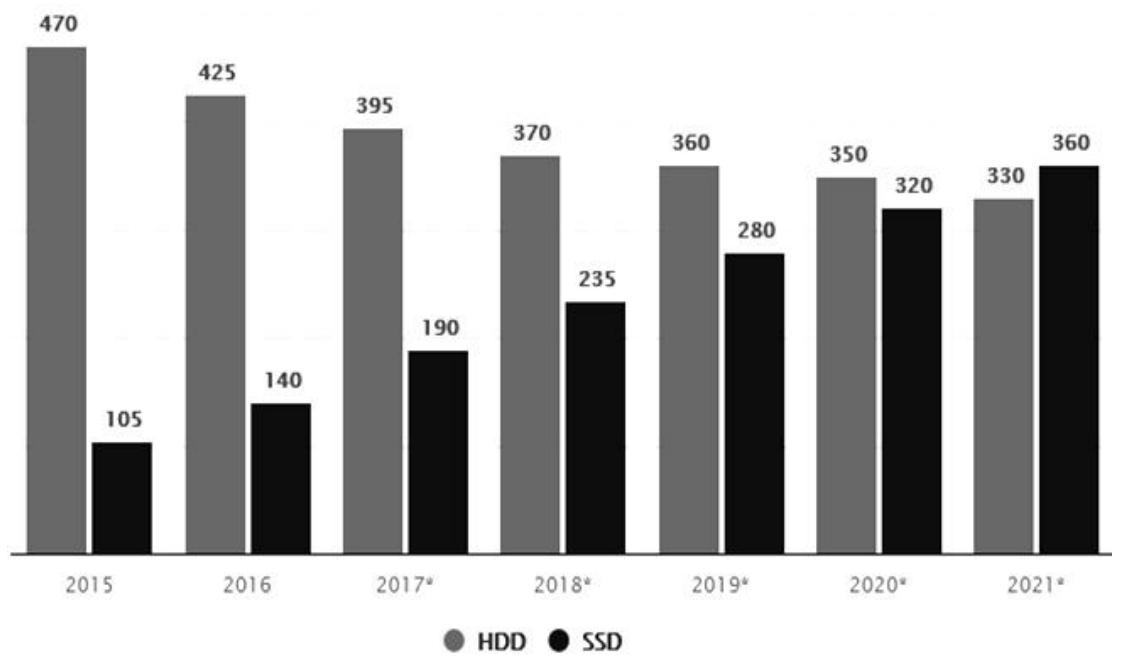

Рис. 2. Динаміка обсягів (у міліонах) виробництва жорстких магнітних дисків і SSD-пам'яті [9]

Серед інших типів магнітних носіїв, які використовуються для довготермінового зберігання даних треба згадати магнітні стрічки. Магнітну стрічку вже не використовують як універсальне сховище даних, але вона застосовується для довготермінового зберігання та архівування резервних копій. Щоб продовжити використання магнітних стрічок, компанії, які їх виготовляють удосконалюють попередні рішення і розробляють нові перспективні моделі. Наприклад, Spectra Logic LTO-8 підтримує зберігання «нестиснених» даних об'ємом 12 Тбайт, а швидкість їхньої передачі становить 427 МБ/с. Ці рішення вже застосовуються у стрічковій 
бібліотеці HPE TFinity ExaScale, яка забезпечує зберігання до 1,6 ексабайт даних [10]. Зменшення розміру зони запису окремих інформаційних бітів призводить до значного зменшення гарантованого терміну зберігання даних, більшого впливу на записані дані теплових коливань оточуючого середовища. Таким чином, жорсткі диски з високою ємністю мають низький термін служби і не підходять для довготермінового зберігання даних [3].

Стрімке зростання обсягу цифрових даних і необхідність довготермінового зберігання більшої частини цих даних роблять необхідним пошук альтернативних, більш економічних способів, ніж зберігання даних на магнітних стрічках і HDD [11].

\section{Оптичні носії Амя систем архівного зберігання даних}

Оптичні накопичувачі протягом багатьох років були одним із найбільш популярних способів зберігання даних. Розповсюдженість цієї технології була обумовлена великою інформаційною ємністю оптичних дисків і стабільністю довговічністі такого носія [12] порівняно з іншими носіями магнітного та магнітооптикного запису. Тим не менш, систематичний аналіз свідчить про те, що у сучасних інформаційних технологіях місце і значення оптичних носіїв значною мірою змінилися. Можна передбачити, що у найближчому майбутньому оптичні приводи будуть повністю видалені з більшості стаціонарних і мобільних комп'ютерів, оптичні диски будуть усе менше використовуватися для зберігання великих об'ємів даних, перенесення інсталяційних пакетів програмного забезпечення та ліцензійної мультимедійної продукції (фільми, музичні твори, ігри та ін.). Це пов'язано 3 тим, що, порівняно з можливостями сучасного магнітного запису та твердотільними носіями, оптичні диски характеризуються низькою щільністю запису інформації і швидкістю іiї передачі [13]. Крім того, на сьогоднішній день значні об'єми даних передаються широкими мережевими каналами та зберігаються центрами обробки даних і хмарними сервісами, що $є$ більш зручним і забезпечує ефективний захист від зловмисних дій. Але слід зауважити, що оптичний запис інформації через особливості реєстрації даних у вигляді мікрорельєфу зберігає своє значення для архівного зберігання даних і у даній області може вважатися найбільш перспективним підходом. Головним фактором, який обмежує широке використання оптичних носіїв $є$ їхня недостатня ємність. Кращі зразки оптичних носіїв довготермінового зберігання Archival Disc (Archival Disc компаній Sony and Philips) мають ємність 300 Гбайт зі строком зберігання 100 років. У цих дисках для забезпечення надійного зберігання даних використовується одноразовий запис. Прискорене тестування Archival Disc на старіння дозволяє виробникам стверджувати, що середній термін служби архівного диска становить не менше 100 років при температурі $30{ }^{\circ} \mathrm{C}$ і відносній вологості 70 \%. Забезпечити таку ємність носія вдалося за рахунок використання тришарового запису та здійснення запису даних як у направних доріжках, так і в зонах між доріжками. Розробники планують збільшення ємності Archival Disc до 3,3 Тбайт [8]. Крім компанії Sony, 3 2018 року тайванська компанія Ritek буде випускати оптичні диски AD [14]. Дослідження в галузі методів оптичного запису спрямовані на збільшення строків зберігання даних та ємності оптичних носіїв за рахунок використання методів нанотехнологій. Зокрема, створення оптичної пам'яті для довготермінового збері- 
гання даних планується 3 використанням наноплазмонного запису на гібридних скляних нанокомпозитах. Інформація записується на золотих нанорозмірних дротах, що включені до скляної матриці (рис. 3). Висока щільність запису на таких носіях забезпечується завдяки багаторівневому запису, ємність таких носіїв може становити понад 10 терабайт. Ці носії можуть забезпечити зберігання даних протягом 600 років, що відкриває нові можливості для створення довготермінової пам’яті даних [7]. Розробка такого носія виконана австралійськими вченими.
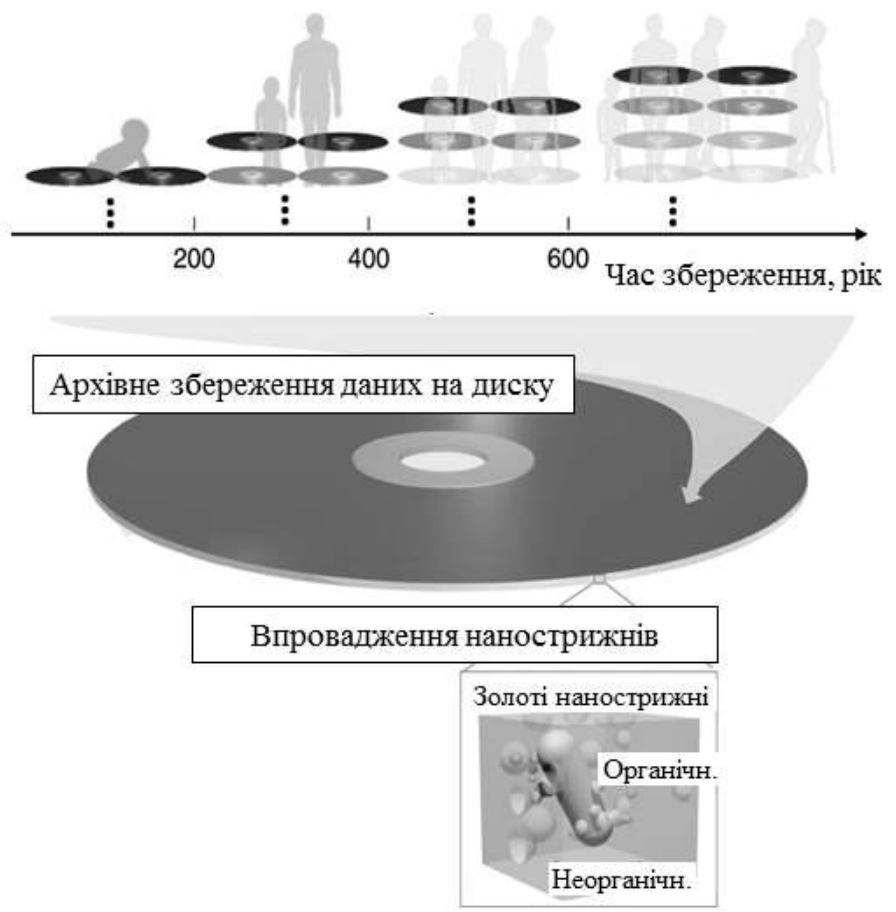

Рис. 3. Оптична пам’ять на золотих наночастинках [3]

Для перевірки надійності та функціональності даного класу оптичної пам'яті на розроблених композитах було використано спеціальну технологію запису та зчитування інформаційних блоків, що включала використання імпульсів фемтосекундного лазерну. Формування нанострижнів у матриці реєструвального середовища, що характеризувалася більшим модулем Юнга, було вивчено через аналіз спектрів розсіювання окремого нанострижня. Крім збільшення строку збереження інформації, збільшення модуля Юнга для композитів дозволяє здійснити точний контроль форми нанострижнів, що необхідно для формування багаторівневої оптичної пам'яті даних високої інформаційної ємності.

Використання оптичних носіїв для архівного зберігання даних пов'язують також з голографічними запам'ятовуючими пристроями, в яких будуть використовуватися нові нанокомпозитні матеріали. Технологію голографічного зберігання даних було запропоновано декілька десятиліть тому. Головна перевага голографічного зберігання даних полягає в тому, що воно забезпечує об'ємний запис інформації. Було реалізовано тільки декілька голографічних запам'ятовуючих пристроїв. У 2005 році було розроблено технологію голографічних універсальних дисків (HVD), а в 2009 році компанія General Electric представила подібну техно- 
логію власної розробки. Запропонована технологія не була доведена до рівня широкого практичного застосування. Очікується, що в майбутньому голографічне зберігання отримає більше досягнень і буде розвиватися, щоб задовольнити всі вимоги до зберігання даних і зменшити фінансові витрати цифрових бібліотек [3, 15].

Вважається, що використання нових наноструктурованих фоточутливих матеріалів дозволить вирішити кілька головних проблем, які раніше перешкоджали практичному застосуванню пристроїв голографічного запису та зберігання інформації. Розроблено декілька типів композитних наноструктурованих матеріалів. Основою одного з таких матеріалів є тонкий напівпровідниковий шар, що складається $з$ діоксиду титану та срібних наночастинок. Лазер записує інформацію саме у срібні наночастинки, змінюючи їхній заряд, дані можна зберігати у вигляді тривимірних голограм, тому що різні довжини хвиль лазерного світла впливають на наночастинки різними способами. Розрахунки показують, що на плівку розміром $10 \times 10$ сантиметрів і товщиною 620 нанометрів можна записати інформацію обсягом близько 8,5 Тбайт. Для запобігання випадковому видаленню інформації ультрафіолетовим світлом на фоточутливий матеріал наносять додатковий шар завтовшки до двох нанометрів, що захоплює електрони, вибиті з матеріалу фотонами ультрафіолетового світла [16]. Пропонується також фоточутливий матеріал, в якому прозорі кварцові наночастинки у кількості 25 відсотків від загального обсягу рівномірно розподілені по полімерному матеріалу, що складається з суміші мономерів декількох типів [17].

Проблема довготермінового зберігання даних вирішується створенням спеціальних носіїв інформації з оптичним зчитуванням, в яких використовується представлення даних у вигляді мікрорельєфних структур на поверхні високостабільних матеріалів (пропонується використовувати скляні, кварцові, кремнієві, нікелеві або вольфрамові підкладки) [18].

Для довготермінового зберігання стратегічно важливої інформації запропоновано виготовляти підкладки оптичних носіїв із синтетичного сапфіру [19]. Невелика ємність таких носіїв, яка відповідає ємності стандартних CD або DVD, обмежує їхнє широке використання. Доцільно використовувати їх для зберігання найбільш важливої інформації.

Сучасні оптичні диски здатні гарантувати зберігання даних більше 50 років без міграції, однак недостатня ємність і швидкість передачі даних з окремих оптичних дисків, порівняно з магнітними жорсткими дисками або стрічками, істотно обмежили їхнє використання в центрах обробки даних. Тому значна увага приділяється створенню роботизованих систем зберігання даних на оптичних дисках, в яких використаються тисячі оптичних дисків [11]. Для таких сховищ створюється ієрархічна система зберігання даних на базі SSD, жорстких магнітних дисків та оптичних дисків для зменшення часових затримок у механічних пристроях.

\section{Твердотімьна пам'ять Амя систем архівного зберігання даних}

Забезпечити зберігання великих обсягів інформації можуть новітні типи твердотільної пам'яті. За даними компанії IDC, у 2017 році вартість ринку allflash-пам'яті в корпоративному секторі зросла на 76 \%. При цьому вартість продажу гібридних флеш-масивів досягла 2 млрд. доларів. Компанія Technavio пов’я- 
зує зростання популярності й обсягів продажів SSD зі зниженням цін на ці пристрої. Очікується, що в 2018 році виробники продовжать знижувати ціни на флешнакопичувачі.

Порівняно $з$ жорсткими магнітними дисками, частка інформації, яка зберігається на твердотільній пам’яті, постійно збільшується (рис. 4) [20].

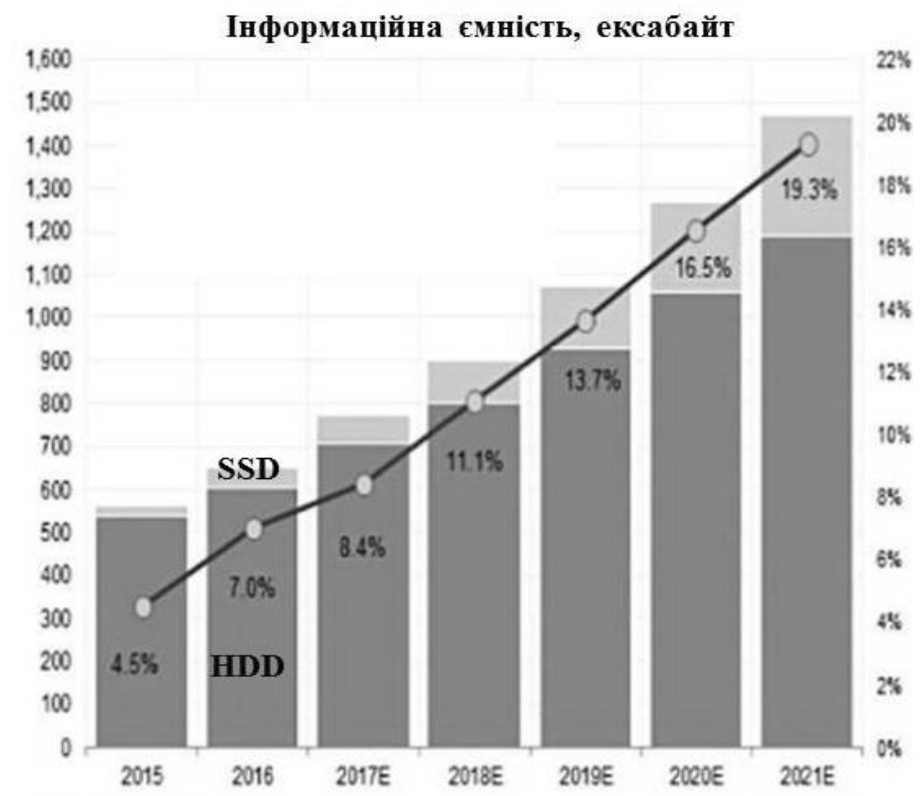

Рис. 4. Співвідношення обсягів даних, які зберігаються на жорстких дисках і твердотільній пам'яті [20]

Серед компаній, які віддають перевагу використанню в своїх центрах обробки даних твердотільних накопичувачів замість жорстких дисків, можна відзначити Calligo, Facebook i Dropbox. Facebook, наприклад, задіють SSD з інтерфейсом PCI-E, представники компанії вважають, що флеш-пам'ять добре показує себе при обробці запитів [2].

Забезпечити зберігання великих обсягів інформації можуть новітні типи твердотільної пам'яті. Забезпечити тривалі строки зберігання даних можуть носії, виготовлені за технологією 3D Xpoint, в яких реалізовано багатошарове зберігання даних з використанням запису даних на основі змін фазового стану речовини. На зберігання інформації за цією технологією не впливає виток електронів, який накладає обмеження на термін зберігання інформації у стандартній флеш-пам'яті. У пам'яті 3D XPoint інформація зберігається у вигляді змін фізичного стану речовини, а саме значення записаних одиниць визначається за електричним опором комірки. Електричний опір матеріалу, що використовується в блоках 3D XPoint, залишається незмінним і після зняття напруги. Перше покоління 3D XPoint має двошарову структуру та виконується за 20-нанометровим технологічним процесом. 3 подальшим застосуванням EUV-літографії планується перехід до 10-нанометрової технології зі збільшенням кількості шарів у структурі пам'яті 3D XPoint. Технологія 3D XPoint $є$ принципово новою і багатообіцяючою технологією енергонезалежної пам'яті, яка створена компаніями Intel i Micron (Intel просуває іiі за 
власним маркетинговим ім'ям «Optane»). Смність носіїв, що виготовлені за технологією 3D Xpoint, може сягати декількох сот Гбайт (ємність носія Optane SSD DC P4800X, призначеного для використання у центрах обробки даних, становить 375 ГБ). Однією з головних переваг накопичувача Optane P4800X є тривалий термін служби. Витривалість даного SSD оцінюється на рівні 30 перезаписів на день (DPWD - Drive Writes Per Day), а сумарна кількість записуваних байтів TBW (Total Bytes Written), тобто загальний обсяг інформації, яку можна записати на носій протягом всього терміну його експлуатації, складе 12,3 петабайта. Вартість зберігання 1 ГБ даних на такому носії становить близько 4 доларів [21]. У травні 2018 року компанія Intel представила нову модель - Optane 905Р. Рішення доступно в двох форм-факторах: HHHL і в корпусі 2,5 дюйма. Смність пристрою становить 960 ГБ, швидкість послідовного читання даних - 2500 КБ/с, а послідовного запису - 2000 КБ/с [2].

\section{Сховища майбутнього Амя довготермінового зберігання інформації}

Для забезпечення довготермінового зберігання інформації використовувалися, крім вищезгаданих носіїв, також мікрофільми, які можуть забезпечити термін зберігання даних протягом сотень років. У мікрофільмових носіях інформації застосовуються сучасні технології кодування інформації з використанням штрихових кодів, які подібні QR-кодам. Норвезька компанія Piql розробила технологію зберігання даних на мікрофільмах, яка забезпечує термін зберігання даних 500 років і використовується для створення сховищ стратегічно важливої інформації. Головним фактором, який обмежує широке застосування таких носіїв, є необхідність зберігання у жорстко визначених кліматичних умовах (відносна вологість $55 \pm 5 \%$ при температурі $17-19^{\circ} \mathrm{C}$ ). Для довготермінового зберігання мікрофільмів і мікрофіш будують спеціальні сховища (часто підземні) [22].

Дослідники, які займаються створенням технологій довготермінового зберігання даних, у своїх розробках створюють принципово нові системи. Значні потенційні можливості для довготермінового зберігання великих обсягів інформації мають носії на базі ДНК. Технологію зберігання даних на ДНК було визначено як перспективну ще на початку 1960-х років, і з тих пір ДНК, як система зберігання інформації, активно досліджувалася. Дослідження показали, що пам'ять на ДНК має значний потенціал із забезпечення довготермінового зберігання великих обсягів інформації. Було обгрунтовано граничні значення щільності запису, розроблено методи кодування з використанням складових ДНК, запропоновано та досліджено схеми запису та відтворення інформації, виготовлено діючі зразки пам'яті 3 використанням ДНК. Однак залишаються невирішеними проблеми забезпечення високих значень швидкості запису та відтворення (секвенування) великих обсягів даних. Залишається також проблемним питання про умови зберігання ДНК-носіїв [23]. Аналітичний огляд досліджень зі створення ДНК-пам'яті представлено у роботі [24].

Дослідникам із Гарварду, які працюють над розробкою ДНК-сховищ вдалося записати у ДНК-код живої бактерії короткометражний фільм. Для запису та зчитування інформації біологи використовували систему коротких паліндромних повторів, регулярно розташованих групами (CRISPR - Clustered Regularly Interspaced Short Palindromic Repeats). CRISPR є системою організації прямих повторів 
та унікальних послідовностей у ДНК-коді мікроорганізму, що розділяють даний код і разом з асоційованими генами (CRISPR-associated genes) забезпечують захист клітини від чужорідних генетичних елементів (бактеріофагів, плазмід тощо) [2]. На сьогоднішній день CRISPR-касети виявлені в геномах багатьох бактерій. Повтори мають довжину від 24 до 48 пар нуклеотидів і при цьому розділені варіабельними ділянками ДНК (спейсерами) приблизно однакової довжини. Дослідники закодували бажану інформацію у спейсери та передали їі бактеріям під виглядом вірусної ДНК $[25,26]$.

Microsoft спільно з Вашингтонським університетом працюють над створенням ДНК-сховища 3 довільним доступом. На початку 2018 роки їм вдалося закодувати та безпомилково відновити більше 400 Мбайт даних. Надалі обсяг сховища планується збільшити до 1 Тбайт і більше, а в Microsoft навіть будують плани з додавання ДНК-сховища до своєї хмарної платформи [27].

\section{Висновки}

1. Системи довготермінового зберігання інформація створюються з використанням цифрових носіїв з різними термінами зберігання даних. Зберігання інформації, що записанана носії зі строками зберігання 3-5 років, вимагає проведення постійного перезапису даних на нові носії, що суттєво збільшує вартість зберігання даних і зменшує надійність зберігання даних.

2. Носії з оптичним зчитуванням не вимагають оновлення записаної інформації або міграції даних, що значно зменшує вартість зберігання даних. Головною проблемою широкого використання оптичних носіїв для довготермінового зберігання даних є значно менша ємність порівняно з жорсткими дисками та твердотільною пам'ятью. Напрямком збільшення ємності оптичних носіїв $є$ використання наноструктурованих реєструвальних середовищ і наноплазмонних методів запису даних.

3. У системах довготермінового зберігання інформації починають використовуватися спеціальні твердотільні носії інформації.

4. Одним із найбільш перспективних типів пам'яті для довготермінового зберігання даних є носії на основі ДНК. age-2025

1. New Approaches for A New Data Age. URL: https://www.seagate.com/gb/en/our-story/data-

2. Хранение данных: краткий обзор трендов этого года. URL: https://itnan.ru/ post.php?c=1\&p=359350

3. Qiming Zhang, Zhilin Xia, Yi-Bing Cheng \& Min Gu. High-capacity optical long data memory based on enhanced Young's modulus in nanoplasmonic hybrid glass composites Nature Communications. 2018. Vol. 9. Article number: 1183.

4. Архівами опікуватиметься ЮНЕСКО. URL: https://ukurier.gov.ua/uk/arhivamiopikuvatimetsya-yunes.

5. Park S. Macroscopic 10 Terabit - per - Square Inch Arrays from Bloc Copolymers with Lateral Order. Science. 2009. 323(5917). P. 1030-1033.

6. Wasim Ahmad Bhat. Long-term preservation of big data: prospects of current storage technologies in digital libraries. Library Hi Tech. 2018. Vol. 36. Issue 3. P. 539-555. https://doi.org/10.1108/LHT-06-2017-0117 
7. Стеклянные пластины - основа жестких дисков будущего, объемом более 20 TБ. URL: https:/quibbll.com/66524-steklyannye-plastiny-osnova-zhestkih-diskov-budushhego-obemom-bolee-20-tb/

8. Shah A. Sony cranks up optical disc storage to 3.3TB. URL: https://www.techhive.com/ article/3057230/storage/sony-cranks-up-optical-disc-storage-to-33tb.html

9. Shipments of hard and solid state disk (HDD/SSD) drives worldwide from 2015 to 2021 (in millions). URL: https://www.statista.com/statistics/285474/hdds-and-ssds-in-pcs-global-shipments-20122017

10. Christine Taylor 2018 Data Storage Market Overview. URL: http://www.enterprisestorageforum.com/storage-management/2018-data-storage- market-overview.html

11. Jie Yao,Qiang Cao,Changsheng Xie,Hong Jiang,Wenrui Yan ROS: A Rack-based Optical Storage System with Inline Accessibility for Long-Term Data Preservation. EuroSys' 17 Proc. of the Twelfth European Conference on Computer Systems Belgrade, Serbia. April 23-26, 2017. P. 161-174.

12. Petrov V.V., Kryuchyn A.A., Beliak Ie.V., Lapchuk A.S. Multi-Photon Microscopy and Optical Recording. National Academy of Sciences of Ukraine, Institute for Information Recording. Kyiv: Akademperiodyka, 2016. 156 p. ISBN 978-966-360-311-7.

13. Death of the Computer Optical Drive Why Most Moderns PCs Do Not Feature CD, DVD or Blu-ray Drives. URL: https://www.lifewire.com/death-of-the-computer-optical-drive-832403

14. Ritek будет выпускать оптические диски AD объемом 300 ГБ. URL: https://www.ixbt.com/news/2018/05/15/ritek-ad-300.html

15. Anderson K., Ayres M., Askham F. and Sissom B. Holographic datastorage: science fiction or science fact? SPE Optical Engineering + Applications, International Society for Optics and Photonics. 2014. P. 920102-920110.

16. Shuangyan Liu, Shencheng Fu, Xintong Zhang, Xinnong Wang, Lihong Kang, Xiuxiu Han, Xi Chen, Jiarui $\mathrm{Wu}$, and Yichun Liu. UV-resistant holographic data storage in noble-metal/semiconductor nanocomposite films with electron-acceptors. Optical Materials Express. 2018. Vol. 8. Issue. 5. P. 1143.

17. Kohta Nagaya et al. Readout fidelity of coaxial holographic digital data page recording in nanoparticle-(thiol-ene) polymer composites. Japanese Journal of Applied Physics. 2016. DOI: 10.7567/JJAP.55.09SB03.

18. Петров В.В., Крючин А.А., Шанойло С.М., Беляк С.В., Мельник О.Г. Технології створення оптичних носіїв для систем довготермінового зберігання даних. Реєстрація, зберігання $i$ оброб. даних, 2017. Т. 19. № 1. С. 3-13.

19. Petrov V.V., Semynozhenko V.P., Puzikov V.M., Kryuchyn A.A. [et al.]. Method of aberration compensation in sapphire optical discs for the long term data storage. Functional Materials. 2014. Vol. 21. N 1. P. 105-111.

20. Chris Mellor SSD price premium over disk falling. URL: https//www.theregister.co.uk/ 2017/05/22/ssd_price_premium_over_disk_falling/

21. McKane $\bar{J}$. How ultra-fast $3 \overline{\mathrm{D}}$ XPoint memory could revolutionise PC hardware. URL: https://mybroadband.co.za > News > Hardware

22. How To Preserve \& Store Microfilm or Microfiche. URL: https//www.recordnations.com/ articles/preserve-microfilm/

23. Erlich Y., Zielinski D. Capacity-approaching DNA storage bioRxiv preprint first posted online Sep. 9, 2016. Doi: http://dx.doi.org/10.1101/074237.

24. Крючин А.А., Беляк Є.В., Крючина С.А., Потебня А.В. Стан і проблеми створення ДНКпам’яті. Медична Інформатика та інженерія. 2015. № 3(31). С. 9-16.

25. Taking cells out to the movies with new CRISPR technology. URL: https://wyss.harvard.edu/ taking-cells-out-to-the-movies-with-new-crispr-technology/

26. Samuel Greengard Cracking the Code on DNA Storage Communications of the ACM. July 2017. Vol. 60. N 7. P. 16-18. DOI:10.1145/3088493

27. Alan Boyle on February 20, 2018 at 5:39 pm DNA data storage system rises past 400 megabytes — find out how to store yours. URL: https://www.geekwire.com/2018/dna-data-storagesystem-rises-past-400-megabytes-find-store/ 